\title{
Kernos
}

Revue internationale et pluridisciplinaire de religion grecque antique

33 | 2020

Varia

\section{Senza paradiso. Miti e credenze sull'aldilà greco}

\section{Karolina Sekita}

\section{OpenEdition \\ Journals}

\section{Electronic version}

URL: https://journals.openedition.org/kernos/3538

DOI: $10.4000 /$ kernos.3538

ISSN: 2034-7871

\section{Publisher}

Centre international d'étude de la religion grecque antique

\section{Printed version}

Date of publication: 31 December 2020

Number of pages: $325-327$

ISBN: 978-2-87562-264-8

ISSN: 0776-3824

\section{Electronic reference}

Karolina Sekita, "Senza paradiso. Miti e credenze sull'aldilà greco", Kernos [Online], 33| 2020, Online since 31 December 2020, connection on 06 December 2022. URL: http://journals.openedition.org/ kernos/3538 ; DOI: https://doi.org/10.4000/kernos.3538

This text was automatically generated on 6 December 2022

All rights reserved 


\title{
Senza paradiso. Miti e credenze sull'aldilà greco
}

\author{
Karolina Sekita
}

\section{REFERENCES}

Doralice FABIANO, Senza paradiso. Miti e credenze sull'aldilà greco, Bologna, Il Mulino, 2019. 1 vol. 13,5 × 21,2 cm, 278 p. (Antropologia del mondo antico, 12). ISBN : 978-88-15-27996-5.

1 This book offers a welcome synthesis of what we may tentatively label as ancient Greek conceptions regarding the world after death. It assumes a dual methodological perspective, that of historical anthropology and that of the history of religions. It is aimed at a general reader, especially Italian (e.g., p.11), but scholars of many disciplines will undoubtedly benefit from the variety of interesting observations and the perspective on the topic it provides.

2 The book opens with an introduction which lays out the methodological perspectives employed and provides a summary of the subsequent chapters. The book's main discussion falls into two parts (further divided into five chapters), dedicated to the presentation of the dead and their world, and to post-mortem punishments. The study is closed by an extensive and up-to-date bibliography (36 pages), which, together with the thoroughly annotated literary sources, students and scholars alike will find very useful. However, the work lacks overall conclusions, and no indices are provided; these omissions leave the reader rather puzzled and dissatisfied. Neither of the two main parts is given any conclusion either, even though some of the chapters include occasional summarising remarks.

3 The style of the book may appear quite contrary to expectations: although it emerges from Doralice Fabiano's [hereafter D.F.] doctoral research, its tone is descriptive and reader-friendly; most of the time, it presents interpretations widely accepted in scholarship and rarely engages in controversial disputes. Only in the second part (e.g., 171 n. 11, 172, 176, 205) does D.F. adopt an open argumentative position; otherwise, 
views contrary to those followed all throughout the text are confined to references in the notes and left without much discussion. The choice of style, however, does not undermine the book's value as a detailed synthesis (especially given the multiplicity of scholarly takes on this topic proposed hitherto) nor does it detract from the validity of its anthropological perspective.

4 The first part (chapters 1-3) is meant by D.F. (p. 11) as a general introduction to the representations of the Underworld - her intention is to address the lack of a comprehensive treatment of the topic available to the Italian reader which would be based on more than simply the ancient literary evidence. D.F.'s discussion is organised around three main themes: (i) the dead, where D.F. analyses what she calls 'substitute bodies' ("corpi sostitutivi", p. 18) by which the individual is represented or signalled in the world of the living and that of the dead after death (the corpse, the psyche, and the tomb); (ii) the food of the dead, which discusses various contexts and types of offerings to the dead and locates the deceased in a communal structure which gives them different social and at the same time 'alimentary' identities, categorised as 'the foreign dead', 'the guest dead', and 'the parasite dead'; and (iii) the world of the dead itself, where particular attention is given to three typologies of that place which correspond, according to D.F. (p. 87), to three different points of view from which the Underworld can be described. These are: (a) external (from the perspective of the world of the living), (b) the liminal space between life and death, and (c) internal (from the perspective of the dead); all these perspectives reflect the geographical orientations and the aquatic components of the Underworld. It is slightly frustrating, however, that in spite of D.F.'s dissatisfaction (expressed in the introduction) with the treatment of this topic in Italian literature, which does not take archaeology into consideration, the references to archaeological research in this part are few, even though they could make her observations more balanced (e.g., in the case of funerary practices). ${ }^{1}$ Equally surprising is also the lack of any proper assessment of blood, mentioned (p. 30) as a prominent element nourishing the senses of the dead and actually reviving their memory in Book 11 of the Odyssey, which is reduced (in the chapter on liquid offerings, p. 53ff.) to a treatment conflating it with wine on the basis that it 'makes good blood' and increases the menos which the dead lack. This observation is interesting in its own right, but it should not be a sufficient reason for D.F. to desist from analysing the broader meanings of blood, given that (as she mentions) it was used in rituals and that she provides a thorough treatment of other liquid offerings. Finally, imagery present in funerary inscriptions could have received more attention in this part, rather than being confined to references to the existing studies on the topic.

5 The second part of the book (chapters 4-5) focuses on the Underworld punishments. D.F. starts with the theme of the Underworld judgement, which she analyses in juxtaposition with the ancient scepticism about myths concerning post-mortem judgement, with particular attention to the vocabulary used: rhetorical (p.136ff), judicial (p. 149ff), and medical (p. 159ff). She stresses that the idea of retribution is weak and that a judicial imaginary is scarcely present in the Underworld; differentiation among the dead in terms of lot after death seems to be confined to initiation into mystery rites, or the lack thereof. The fifth and last chapter presents and analyses in great detail the individual figures who undergo punishment in the Underworld: Tityos, Sisyphos, Tantalos, Peirithoos, Ixion, Oknos, the Danaids, as well as the broad category of the 'uninitiated', with a special focus on cyclical, eternal and immutable features of their punishments, as well as the possible reasons and patterns 
behind them. This part revives various themes discussed in part one (oblivion and memory, nourishment, fixity, impurity, mud and water) and puts them 'to work'. This discussion brings in more novel interpretations, and more archaeological material is used to illustrate the argument. However, it also includes some quite speculative treatments, such as, for instance, the conclusion that Sisyphos has a direct connection to the world of initiations just because he supposedly shares a space on an amphora (no picture or description provided) with 'those who are not initiated' (p. 234: "In una celebre anfora, i non iniziati condividono infatti la scena con Sisifo, senza che questo ovviamente significhi che Sisifo intrattiene una stretto legame con il mondo delle iniziazioni").

D.F.'s choice of the thematic arrangement of material over the chronological is slightly problematic; indeed, it may be the most substantial drawback of the study. As a result, the work lacks any attempt to signal (and thus explain) changes over time in views, imagery, and conceptions connected with the Underworld. The second part of the book is definitely more robust in terms of its chronological perspective than the first, but one still cannot escape the impression that the picture which emerges is too homogeneous and synthetic, bringing together synchronously material spanning more or less a thousand years and covering sources as disparate as Homer and the Byzantine lexicographers. Some caution should have been also applied to the viability and reliability of later sources when used to illuminate early concepts. Besides, most of the analysis is carried out without attention to genres and their specific purposes - it does not acknowledge that the significance and aim of some passages may be peculiar to the texts in which they occur rather than reflecting the actual ancient attitudes.

7 Last but not least, since the target audience is presumably intended to be as wide as possible, the book would benefit from a more systematic quoting of ancient sources: currently, in several places either Greek is not translated or the translation given is not accompanied with Greek in the note; the use of transliteration of Greek words is also far from consistent.

In general, in spite of some drawbacks, the book certainly offers a lot of valuable observations and fresh perspectives on various 'underworldly matters', and especially in those moments when the sources analysed are set against a defined cultural and historical background. Here I think mainly of D.F.'s discussion of particular concepts regarding punishment in the second part, which is accompanied by a long digression on their cultural significance. One might also cite with approval her various interpretations in the first part concerning food of the dead or the underworld sources of water and their significance. The abundance and variety of sources used by D.F. as well as her thorough bibliographical annotations are of considerable value for specialists. The smooth style of writing in turn makes following the analysed material easy and enjoyable for the general reader as well. Thus, overall, the book constitutes a very useful source of ideas and inspiring perspectives for anybody interested in the imagery of the ancient Greek Underworld. 


\section{NOTES}

1. I refer here in particular to the extensive research on unusual burials by Maria Liston (University of Waterloo, Canada). Too recent to have been considered by D.F. but no less

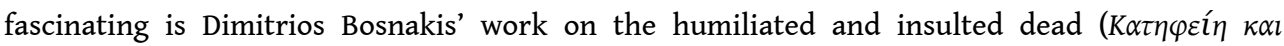

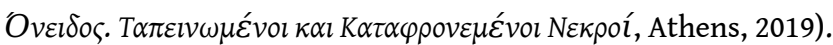

\section{AUTHORS}

\section{KAROLINA SEKITA}

University of Oxford 